\title{
Trajectory of Subject in the Space of Politics and Arts: The Artist, his Body and State Apparatus (Pavlensky's Case)
}

\author{
Vyacheslav Kombarov \\ University of Novosibirsk, Institute of Economics and Industrial Engineering
}

Received 31 October $2017 \cdot$ Revised 15 November 2017 • Accepted 23 November 2017

\begin{abstract}
This research investigates bodily art practices of Russian artist and actionist Peter Pavlensky, who uses his naked body in the urban space, creating corporal statements of political order. His body discourse involves the use of body parts, material objects, as well as urban structures which fits the body - endowed with sacred and the political value: Red Square, a psychiatric hospital, etc. Using the approach of Badiou, I will show how body discourse on politics separates from the dominant political discourse in the mainstream media. Point of view of Kristeva on the phenomenon of subject let us to understand how naked body and artist's bodily work constitutes order of signifiers that media audience decodes as political statements. Corporal performance let to subject, deprived of the right to speak, to use his body as language to become the subject of political discourse in artistic sensual way. Act of creation of body text becomes the act of political resistance.
\end{abstract}

Keywords: subject, Pavlensky, Russian media, state apparatus, body.

\section{Introduction}

What can people do in the situation of restrictions and prohibitions? Obviously, in a situation where your discourse is forbidden, you are forced to create a new language. However, this new language should be such that mass media system (which you would like to use) can be able to recognize it as its own, habitual. Niklas Luhmann, a well-known theorist of the mass media, wrote that in order for a message to be recognized by the mass media system as information, it must contain the usual code which the system can describe in its usual language. In other words, the mass media system can describe events, messages, information only in its own language (Luhmann, 2000). Thus Mr. Pavlensky makes a little trick to attract attention for his person - he uses sensationalism, scandal, unusual in his actions - everything that attracts the media so much.

Often in order to overcome discursive restrictions and to be heard, consciously or unconsciously, we use a laughing, carnival culture. In our case, we use carnavalization as a synonym for the concept of theatricalization. Carnavalization let us to put under the sign of the question the one-sidedness of interpretation of the media, offers different options for interpreting the problem covered in the media. Laughter and theatricality tear off covers of falseness from reality, show an imbalance between the external and the internal, and anticipate new things/events (Vice, 1997).

(C) Authors. Terms and conditions of Creative Commons Attribution 4.0 International (CC BY 4.0) apply. Correspondence: Vyacheslav Kombarov, 630090, Novosibirsk, Lavrentieva, 17, room 325, RUSSIAN FEDERATION. E-mail: vkombarov@gmail.com. 
In the case I am writing about, the language is the body language that can be viewed as carnivalized discourse of politics. In the situation, where you can't use speech, the body becomes source of political discursivity.

It's clear that only body itself is not enough to be socially significant, it must be immersed in a socially important context. In order to make statements, the body should interact with the socially significant ambient - urban space, buildings, history, ideology and recent news.

The main concepts I'm using in my research on theatricalization of politics are subjectivation, discourse and sign.

\section{The wall of mass-media}

The sensitive thesis that traditional and new mass media becomes less and less free site for opinion exchange and manifestation of controversial discourses is very actual. This happens in different places of the world. At the same time impact of TV broadcasting, which belongs to traditional mass media, is huge on mass consciousness, despite of social networks and other internet projects existence. According to the surveys more than $85 \%$ of Russian media audience, for example, get news about the Russia and all over the world by television (Volkov \& Goncharov, 2017) (Figure 1).

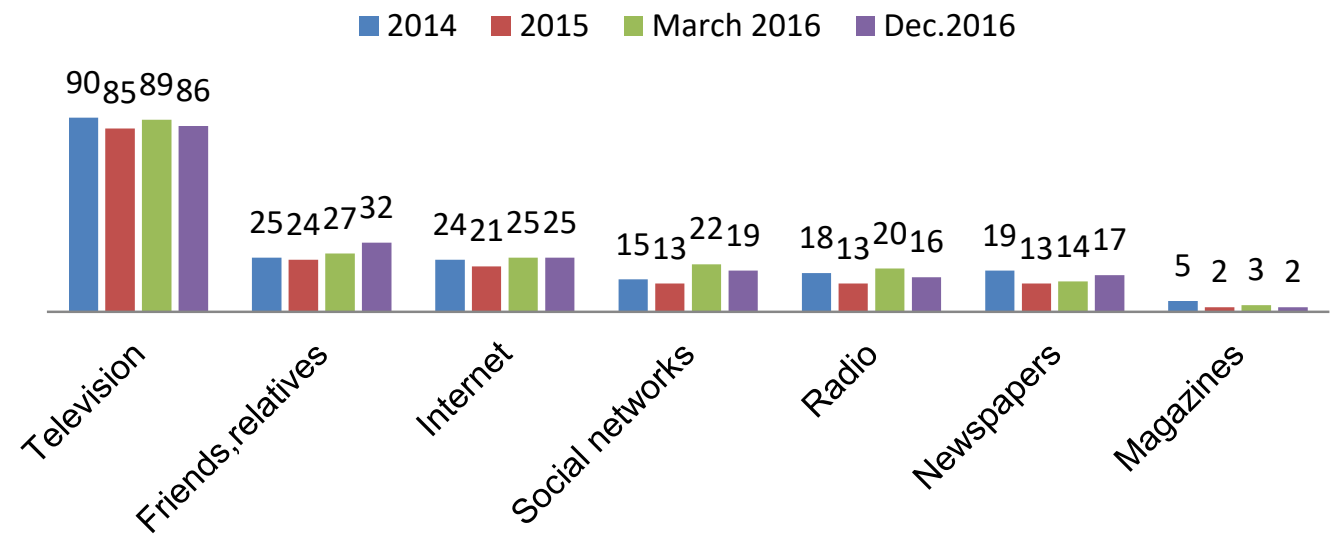

Figure 1. Where do you most often learn about the news in the country and in the world (\%)?

Although we are witnessing the increasing of the number of social network users, their part in whole structure of Internet consumers included in this increasing process are limited to users from 16 to 21 years. Then as many sociologist report, and this is very important factor: "Many of the most popular Internet resources in general reproduce the picture produced by federal TV channels. The state still has many tools for control the information agenda on the Internet. A story with one of the most popular news websites of 'Lenta' is typical example of such state managing of the media. In March 2014, the owner changed the editorials of this media, presumably fearing that journalists cover events in Ukraine, presenting in their materials and reports the position of the Ukrainian leadership" (Volkov \& Goncharov, 2017).

Let's remember the situation around Donald Trump during his electioneer and beginning of presidency - the most powerful American TV channels attacked Trump with criticism. There were been a lot of a fake news. As a result, he had to move his political discourse into social networks and twitter but was attacked there by internet trolls and bots, too.

On the other hand, at the East, in Eastern Europe, and in Russia to be more precise, we are witnessing the collapse of independent television. Almost all informational channels are 
state owned, while commercial independent television is being pushed out of mass broadcasting for various unfair reasons. For example, a law was passed prohibiting Russian media from having foreign funding of more than 20 percent.

I think that we all know about the great Chinese firewall: all incoming news and information is under control in Internet and in TV. 30 percent of the information Chinese receive from the Internet, they receives using VPN. Google and main Western TV channels are blocked there. In North Korea, there is no independent media in principle.

More recently, European Parliament has passed a law at official level that ban broadcasting some of Russian TV channels in Europe. Propaganda was indicated as the reason, but the real reason for the blockage, I suppose, is an alternative point of view that does not coincide with the official version of the European Union government (European Parliament..., 2017). I'm talking about channel "Russia today" for example.

Twitter also has made the policy decision to off-board advertising from all accounts owned by Russia Today (RT) and Sputnik (Twitter..., 2017).

The main issue is that in this space of information wars and censorship, there are real people - an audience that wants to know the truth, even if this truth does not coincide with the opinion of the government or media owners.

And it does not matter, I suppose, which mechanism is used to ban and exclude alternative opinions to main political narratives: financial domination of private media owners or power control on content policy in state media - these two kind of regulation are both contain ideology and censorship in their core. Anyway we could say that regulation could seem softer in commercial media due to multiplicity of content, telecasts and entertainment while it seems to be harder in state media, which seems to be more monolith and directive without intention to hide the ideology. But in fact both mechanisms produce the same thing - reality reduced to one dimensional representation of world, representation tailored according to major ideology of media owners.

This thesis of mine correlates with the concept "Society of spectacle" suggested by French philosopher and sociologist Guy Debord. He divided the world capitalistic system (that includes media as well) into two kinds. One, which spreads spectacle based on consumption (this kind is presented by the West countries) and another, which produces spectacle based on totalitarianism (this is presented by the Eastern countries including ex-USSR). In both parts of the World (Eastern or Western) a human being is alienated and oppressed by capital and the state regulation of everyday life. In the first case they use more manipulative strategies and in the second they use more authoritative strategies.

Debord explains the idea of spread spectacle in such way (Debord, 1977):

"In the image of the society happily unified by consumption, real division is only suspended until the next non-accomplishment in consumption. Every single product represents the hope for a dazzling shortcut to the promised land of total consumption and is ceremoniously presented as the decisive entity. But as with the diffusion of seemingly aristocratic first names carried by almost all individuals of the same age, the objects which promise unique powers can be recommended to the devotion of the masses only if they're produced in quantities large enough for mass consumption. A product acquires prestige when it is placed at the center of social life as the revealed mystery of the ultimate goal of production. But the object which was prestigious in the spectacle becomes vulgar as soon as it is taken home by its consumer - and by all its other consumers. It reveals its essential poverty (which naturally comes to it from the misery of its production) too late. But by then another object already carries the justification of the system and demands to be acknowledged". 
Guy Debord predicted, in his late works, that those two kinds of spectacle will become one - integrated spectacle. Today Eastern media landscape became more varied, full of entertainment and commercial broadcasting, while the state is trying more and more regulate the media in the West.

\section{Pavlensky as subject (desire machine of subjectivation)}

I'm using the concepts subject and subjectivation to underline the differences between so called objectivated and commodified masses of media users and creative subject as he/she resists and transgresses traditional forms of social compulsion through information and language. The subject is trying to be the interpretative artist and not the object of ideology as he thinks and acts in ways that are different from main forms of social communication.

Let me remember the concept of "desire machines" that is basic concept of Deleuze, that explains creativity of subjectivity. Desire machines oppose to "social machines" represented by rigid social structures and hierarchies which we can call machines of information or media machines in our case. The concept "desire machines" reject the idea of an external occurrence, the idea of compulsory causation, focusing on spontaneous self-organization of processuality of the subject (Deleuze \& Guattari, 2004).

In general, social represented by Deleuze theory as a process, not just as a procedural act with its beginning and ending, but as a permanent processuality in which there is no original and derivative, but there is a general drift. Non-integrated and autonomous subjectivities form the configurations of flows.

Although Pavlensky uses the same language to create his installations he does not selfrepeat - all his art works are very different. The main feature of actionism is that the use of the body in the process of creating a work of art does not lead to a complete result, the body does not become a statue or picture, it is in constant development as an element of the artistic language: "In contrast to classical theory of the subject, the present state of its theory and concept can be described more from standpoint of activity and processual approach, rather than a "static" viewpoint: becoming subject is more important than to be subject; to resist, to elude from standardized practices, social procedures, symbolic signification by social institutions - an indispensable condition in attempt to become the subject: "Run Lola Run". Huge role in this process of subjectivation plays phenomenon of "becoming" - a key concept of late postmodernism. In classical theory of formation of subject we are talking about stages and phases that an individual passes to become himself or to become just function of any social organization. Today, "becoming" becomes meaningful in itself as a process of subjectivation. Becoming is valuable in itself and not these species of status and existence which it binds. Goals of becoming contained in itself. Being the subject - is constantly being on the "line of flight" (Kombarov, 2016).

That is exactly what we can see in Pavlensky case. He let any person of the audience to become a subject in process of subjectivation. What Pavlensky shows is not the fixed picture of reality with one meaning. Pavlensky invites audience to be subjects of interpretation and move mentally between his body as signifier and social issues as signified.

On the one hand, desire machines and "social machines" are strongly bound, and on the other hand - essentially alternative to each other. If "social machines" represent the rigid structures focused on constancy and on conservation, then desire machines, on the contrary, are sources of the permanent creativity, which makes a social procedural. Deleuze understood relation between desire machines and "social machines" as relation between micro- and macro-levels of sociality. 


\section{Carcass}

In the comments to his actions, Pavlensky repeats one and the same idea - the enslavement of the human person by state apparatus (Picture 1). He attracts our attention to the increase in the number of laws regulating all spheres of human life in modern Russia: the media, sexuality, political activism and so on.

On May 2013, Pavlensky held a political protest against repressive government policies. His art performance was called "Carcass". His assistants brought him naked, wrapped in a multilayered cocoon of barbed wire, to the main entrance of the Legislative Assembly of Saint Petersburg. The artist remained silent, lying still in a half-bent position inside the cocoon, and did not react to the actions of others until the police with the help of the garden clippers released him.

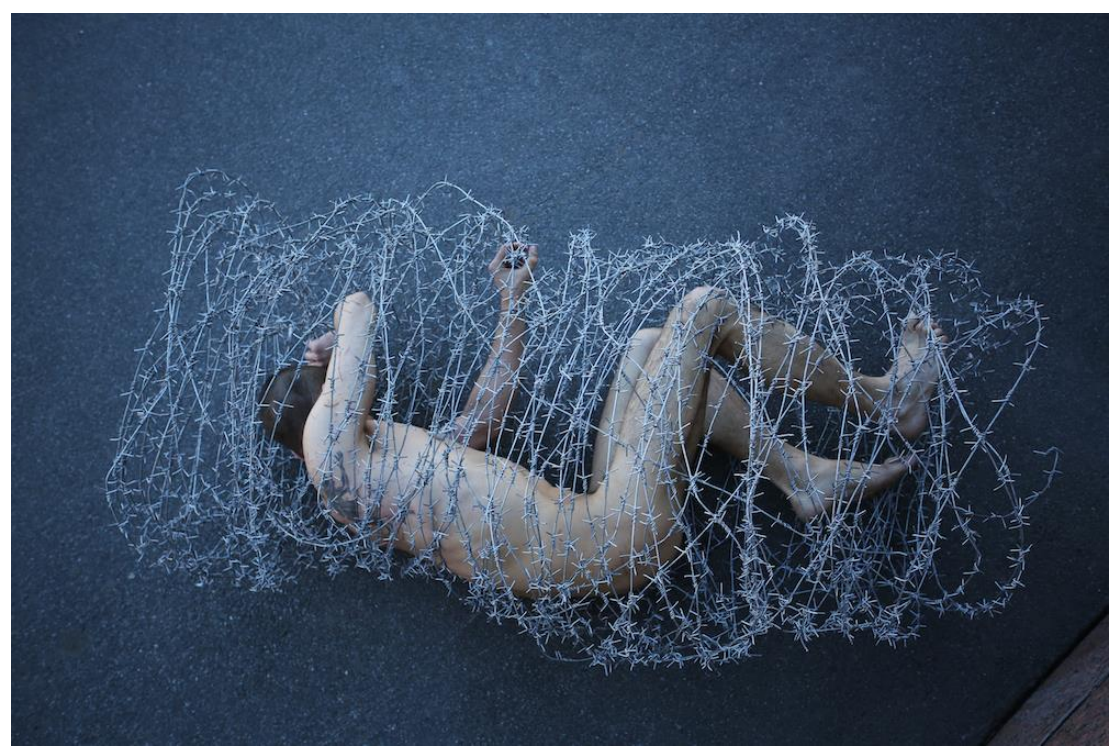

Picture 1. "Carcass" (2013). Photograph: Maxim Zmeev (calveertjournal.com)

Pavlensky's girlfriend mentioned that a metaphor of the action had its immediate realization in the reality: as soon as the barbed wire was cut off, and the artist was freed from it, the same exact wire wrapped him back in with police, ambulances and numerous field investigators (Volchek, 2013).

Pavlensky made the following comment about his artwork (Volchek, 2013):

"Laws aimed at suppressing civic activism, intimidation of the population, steadily growing number of political prisoners, the laws against NGOs, the $18+$ laws, censorship laws, activity of Federal Service for Supervision of Communications, Information Technology and Mass Media, 'promotion of homosexuality' laws - all these laws are not targeting criminals, rather they are issued against all of us. That is why I organized this action. The human body is naked like a carcass, there is nothing on it except the barbed wire, which by the way was invented for the protection of livestock. These laws like this wire keep people in their individual pens: all this persecution of political activists, 'prisoners of May, 6', governmental repressions is the metaphor of the pen with the barbed wire around it. All this has been done in order to turn people into gutless and securely guarded cattle, which can only consume, work, and reproduce".

It corresponds with how Deleuze understand the conflict between social and desires machines: fascist type of integration stops the flows, suffocating them, turning them back and 
dissecting them in accordance with the internal system limits; while becoming subject is running away, and trying to find a gap in the wall that separates him from the production of desire.

\section{From the body to the "I" (to ideal subject)}

Philosopher, sociologist and semiologist Julia Kristeva also highlights the "motility" and desire that characterize the creation of the subject. But being the follower of semiologist Roland Bart she proposes the semiotic version of the subject and subjectivity which automatically disrupts the totalitarianism of system intrinsically connected to subject: that is language. Subject is becoming via language.

Let's remember briefly that semiotics is the academic field dedicated to the study of signs. A sign may be recognized by the presence of its two parts - the signifier (word, images) and the signified (the meaning). Semiotics describes any system of signs: texts, books, images, multimedia productions, fashion, daily social life, etc. As the result social reality is represented as a number of texts. The artist that creates unexpected meanings denoting social reality with body language produces also new subjectivity (of himself and of the media audience).

Kristeva uses the approach of Russian philosopher Bakhtin to study of polyphonic subjectivities and dialogical consciousness that he applied in the study on Dostoevsky. Thus Kristeva postulates that signification of text does not behave according to a universal law. It attacks every structure that says "No" to the subject's impulses. The "unitary" of subject is replaced by subject in process.

In the book Revolution in poetic language she uses also the Hegelian concept of "negation". Kristeva interprets negation as annihilation of the object and introduction of object into the structure of the knower. The structure of subjectivity is bifurcated: subject is understood as sensational subject of desires and bodily needs, and on the other hand, the desiring subject finds himself in the discourse, denoting his biological level through the symbolic (Kristeva, 1984).

To explain her concept of subjectivation lets turn to her essay The signs on the way to the subject. This essay is her semiotic research of the sixth chapter of Gospel of John. It can be read as a semiotic discussion. Jesus opposes to the concept of signs of the Old Testament by providing other interpretations. He includes these signs in the arising theory of the subject (Kristeva, 1993).

John comes into semiotic dispute. His narrative begins with the assimilation of the miracles performed by Jesus to these magical signs, which served as the basis for the faith of believers who lived in pre-Christian era. At first, Jesus is a magician: "He was followed by a lot of people, because they saw the signs, which he did on the sick" (In. 6, 2). Finally, "people saw Jesus walking on the sea" (In. 6, 19). Later, however, the John tried to give a different meaning to these wonders.

John makes here a new semiology through Jesus. Sign fulfills its purpose only if it meets the sensory needs of the recipient. So it is necessary to recognize the bodily needs (hunger, thirst). Using the words of Jesus, John increases the sensory duplication of signs. He interprets the speech as spoken in order to meet the vital needs, "Jesus said to them: you seek Me, not because you saw signs, but because you ate of the loaves and were filled" (In. 6, 26).

Thus, John begins the interpretation of miracles with sensationalism, then goes on to justify the needs up to the symbolic center of the Eucharist. John insists that the external vision does not exhaust the diversity of your experience regarding these "signs". You are not simply acts as a recipient of a miracle-gift, but you exist in time and space of my narrative. Therefore, the second shift becomes possible. John did not forget to bring through these wonders with the food, 
which you need, necessity to move to "I", the need to fully trust to this "I". Who is this "I"? "I am the bread of life" (In. 6, 35), "the Son on whom God the Father has set a seal" (In. 6, 27).

Absolute subject is the "Son of Man", who nevertheless retains close relationship with God as his Father. Talk about fatherhood involves bodily genealogy. The memory of the origin in the context of signs leads back to the body and senses. On the other hand, the word "seal (sceller)" contains a semantic relationship between subjects: the Son "means" the Father, and this meaning is manifested in us, the recipients of the Gospel narrative. Just as the Son entrusted to the Father, you trust to the Son. Signification - it's trust to Other, who associated with the trust, to the Father. Subjectivation is based on this triple relationship.

In other words, we must "come" to "I" without using perceived "visions". From now on, the sign is the trajectory of the subject. This interpretation replaces the sign as a gift.

In Pavlensky's actions, we can see a similar logic: the audience becomes a subject moving between two poles: the body and the idea that this body denoting - signifying. At the beginning the audience is attracted by the sight of the naked body, but then it begins to move mentally towards the subject who is producing idea and is trying to convey this idea to the audience's consciousness. The process of subjectification is that the sensory experience is replaced by an intellectual experience that unites the audience with the artist who speaks through his body language.

The usual passivity of the audience, which, let's say, "eat" what is given to it, is replaced by subjective activity - we understand what Pavlensky says with the help of the body in spite of verbal explanations of TV news which change the meaning of his actions. As it was said above mass media system always seeks to describe events in its ideological language, so the official TV news are trying to change, intercept the signified. For example, for the description of Pavlensky actions it uses stigmatizing expressions such as self-mutilation, the usual practice of prisoners, inadequacy, mentally illness, masochist, exhibitionist etc. It is worth noting that, in this case, the media is trying to keep the meaning of message solely at the level of the body, at the level of object, and thus it is closing the way for the audience towards symbolic meanings of the criticized action.

Despite of this pressure, Pavlensky without using a single word, transforms the audience into a subject, which, contrary to ideological verbal influence can separate truth from lies. The audience thus moves through subjectivation from the silent body as an object to the idea.

\section{Fixation}

In 2013, while sitting naked on the stone pavement in front of the Lenin's Mausoleum on the Red Square, Moscow, Pavlensky hammered a large nail through his scrotum affixing it to the stone pavement. His action coincided with the annual Russian Police Day. When the police arrived, they covered him with a blanket and later arrested him. "A naked artist, looking at his testicles nailed to the cobblestone is a metaphor of apathy, political indifference, and fatalism of Russian society", declared Pavlensky in his statement to the media (Artist Pyotr Pavlensy..., 2013).

The discourse of Pavlensky build the bridge between the corporeality with which we are able to identify ourselves (since we all have hands, feet, head, genitals, empathy as an ability to sense or imagine physical pain) and the ideal "I", which is the history of society that unites individuals into some generalized whole. The image, the sign of this unified "I" as a whole, is appearing from the symbols used by Pavlensky, and which are actually sacred for Russians. For example, let's look at the Red Square. It is considered by many to be "heart" of Russia (heart again as a corporeal phenomenon), where we can find Lenin's mausoleum (where the body of this leader is stored in form of mummy). The Red Square is also the former place of mass executions of criminals in the Middle Ages (red square like red blood). At the same time the Red Square is a 
symbol of Russia's power and greatness. It is a symbol, which creates a sense of the identity of society, the collective "I". In the process of subjectification, this "I" becomes "We" and acquires a pessimistic sound: we are apolitical, apathetic, etc.

At the same time, in the Kremlin, which is separated from the Red Square by a wall, there is the transcendental "I" (separated by a wall) - the president of Russia, the one who corresponds to "the Father" in Kristeva's theory. He represents a transcendental subject, in which the love and hope of Russians are concentrated (the people's love for the president is known according to various sources, about $90 \%$ of Russian population supports the president). Thus, nailing part of his body to the Red Square, Pavlensky, performs the procedure of sealing the people with the "ideal I" - the president. But unlike the case with Christ in the Gospel of John, this identification with the "Father" is negative. Fixation, the identification of the Russian people with the "ideal I" - a symbol of apathy, dependence and helplessness in the face of power, the allegory of sacrifice.

\section{Pavlensky as "apostle” (discoursive analyis)}

I consider installations of Pavlensky as number of texts that is result of using by this artist of his specific body language. Becoming of the language in the specific social context is no other than discourse - the presence of social and politics structures in the language of the subject of statements.

Badiou wants to show that as long as everything goes on as usual the subject does not exist. While knowledge and its accumulation are possible when everything goes in accordance to the rules taken for granted, the truth is impossible. Truth comes to us as an event.

The story of Paul is well known and can be considered as an example here. Heading to Damascus, Paul, a jealous Pharisee persecuting Christians, hears a mysterious voice, which reveals to him the truth. It was blind and far from being dialectical transition - the subject is resurrected in the Paul (Badiou, 2003).

Extraordinary gesture of Paul, according to Badiou, was that he liberated the truth from the effects of the community (whatever form this community takes - group of people, city, Empire, territory, or social class). For what is true (or fair in this case), the subject does not need to appeal to any objective unity - neither according to its reason, nor according to its destination. Paul separates any process of truth from the "cultural" historicity, in which opinion intends to dissolve it.

\section{Stitch}

Pavlensky makes something similar. Artist breaks the habitual course of things - the traditional system of representation of events and news in the mass media: instead of verbally enumerating events and assigning certain values to them in the context of a certain ideology, he appeals to universal values that run counter to the existing state of affairs.

Pavlensky first became known for sewing his mouth shut in political protest against the incarceration of members of the Russian art group Pussy Riot. Pavlensky appeared at Kazan Cathedral, St. Petersburg, with his lips sewn up holding a banner that stated: "Action of Pussy Riot was a replica of the famous action of Jesus Christ" (Matthew, 21: 12-13). Police called an ambulance and sent him for a psychiatric examination; the psychiatrist declared him sane and released him shortly after the incident. The artist stated that he was highlighting the lack of regard for artists in contemporary Russia. He said: "My intention was not to surprise anyone or come up with something unusual. Rather, I felt I had to make a gesture that would accurately reflect my 
situation... there is a general tightening of censorship, a ban on open statements in contemporary art is being introduced. I see how many artists all accept this. The frames gradually narrow. A year ago this was not. I do not like that people, especially artists, take it very easy. And this process over Pussy Riot is a gesture of power state apparatus, which decided to show to all that it's time to shut up" (Komarova, 2012).

There are two consequences of this activity. First of all, if the truth comes from the event, it is singular. Secondly, no one from community is able to dispose of this truth. The truth it's not based on any identity. Truth came from the event. It is intended to everyone without restrictions whatever previous experiences of subject were.

Loyalty to the declaration is important, because the truth is a process. It is not an insight. In order to think and to speak, it is necessary to rely on the three concepts which fix the respective state of the subject: the concept, that names the subject at the time of declaration ("faith"); the concept, that names subject at the time of the active manifestation of their beliefs ("love"); and the concept, that names the subject in his capacity to resist the external oppression ("hope", but it would be better to say "confidence" and "resistance").

The truth is indifferent to the State, for example, to the Roman state. This means that it's free from ideology, which the State prescribes.

Let's touch briefly the Subject in Discours of Paul.

Paul creates a "Christian discourse" by distinguishing it from the actions of the Jewish and Greek discourses. What is the Jewish discourse? The prophet is a subjective figure that creates it. Thus, we can assume that the Jewish discourse is, above all, the discourse of the signs.

The wise man acts as a subjective figure of the Greek discourse. Wisdom is in assignment of the established world order. It is in correlation between Logos and life. The Greek discourse is cosmic. It locates the subject in natural totality.

Deep idea of Paul was the fact that Jewish and Greek discourses are two faces of one and the same figure of domination. Both discourses, Greek and Jewish, are the essence of the Father. That is why they shape community in the form of subordinated dependence (Space, Empire, God, or Law). The ability to become universal, free from all particularism has the only subject who will present himself as a discourse of the Son (Badiou, 2003).

\section{Lubyanka's burning door}

In this action Pavlensky came to the first entrance of the Lubyanka Building, which is the headquarters of the Russian Federal Security Service on November 9, 2015 at 1:15 a.m. Moscow time, and doused the front door with gasoline and set fire to it with a cigarette lighter. The doors of the building were partially burnt. Pavlensky was detained after 30 seconds without resistance, and charged with debauchery. A few hours after the action, a video appeared on the Internet with an explanation of the meaning of the burning (Jonathan, 2015).

According to gallerist Gelman, the action shows Pavlensky's "obvious symbolism". "The Lubyanka door is the gate to hell, the entrance into the world of absolute evil. And against the backdrop of hellfire is a lonely artist, waiting to be captured ... Pavlensky's figure at the door of the FSB in flames - is a very important symbol for today's Russia, both political and artistic" (Russia Update..., 2015).

We can see how the artist, making this action and others, embodies the figure of a son who opposed himself to the symbolic father - the figure of power and violence - to the state apparatus. The artist as a subject is represented only by nude "little" body that put himself in 
opposition to the "big" state apparatus, but despite that this big one was not able to injure him more than himself really did.

\section{References}

... (2013). Artist Pyotr Pavlensky nailed the scrotum to the stone blocks on Red Square https://graniru.org/Politics/Russia/activism/m.221013.html

Badiou, A. (2003). Saint Paul: The Foundation of universalism. Stanford: Stanford University Press.

Debord, G. (1977) [1967]. The society of the spectacle, translation by Fredy Perlman and Jon Supak (Black \& Red, 1970; rev. ed. 1977). http://library.nothingness.org/articles/SI/en/display/18

Deleuze, G., \& Guattari, F. (2004). Anti-Oedipus. London and New York: Continuum, 2004.

... (2017). European Parliament: Report on on EU strategic communication to counteract propaganda against it by third parties (2016/2030(INI))

http://www.europarl.europa.eu/sides/getDoc.do?pubRef=-//EP//TEXT+REPORT+A82016-0290+O+DOC+XML+Vo//EN

Jonathan, J. (2015). Pyotr Pavlensky is setting Russia's evil history ablaze. Retrieved 9 November 2015. https://www.theguardian.com/artanddesign/jonathanjonesblog/2015/nov/og/pyotrpavlensky-is-setting-russias-evil-history-ablaze

Komarova, V. (2012). With widely sutured mouth: Echo of Moscow. - 2012. - Aug, 6. https://echo.msk.ru/blog/publicpost/916475-echo/

Kombarov, V. (2016). Subject of Work and Postmodernity: Ethical and Pre-Rational Approaches // The Futures We Want: Global Sociology and the Struggles for a Better World. View from Russia [Electronic resource]: collected papers The 3rd ISA Forum of Sociology "The Futures We Want: Global Sociology and the Struggles for a Better World" (10-14 July, 2016, Vienna, Austria) / [Editor-in-Chief V. Mansurov]; Russian Society of Sociologists, International Sociological Association. - Moscow: RSS. - 1 DVD ROM [P. 92-96].

Kristeva, J. (1993). Des signes au sujet /Les nouvelles maladies de I'ame. - Paris: Fayard. P. 191-201.

Kristeva, J. (1984). Revolution in poetic language. New York: Columbia University Press.

Luhmann, N. (2000). The reality of the mass media. Stanford University Press.

.... (2015). Russia Update: FSB Seals Entrance of Lubyanka as Artist Pavlensky Awaits Determination of His Case. http://www.interpretermag.com/russia-update-november-10-2015/

... (2017). Twitter: Announcement: RT and Sputnik Advertising. https://blog.twitter.com/official/en us/topics/company/2017/Announcement-RT-andSputnik-Advertising.html

Vice, S. (1997). Introducing Bakhtin. Manchester University Press.

Volchek, D. (2013). Cultural Diary: On Good Friday // Radio Liberty. - 2013. - May, 8.

Volchek, D. (2013). Weekly Review // Radio Liberty. - 2013. - May, 4.

Volkov, D., \& Goncharov, S. (2017). Russian media-landscape: main trends in media using - 2017. https://www.levada.ru/2017/08/22/16440/ 